\title{
LEARNING FROM EDUCATION INNOVATION USING THE 4TU.CEE INNOVATION MAP
}

\author{
Emiel van Puffelen \\ 4TU.Centre for Engineering Education, \\ Wageningen University \& Research, The Netherlands \\ Caroline Vonk \\ 4TU.Centre for Engineering Education, \\ Eindhoven University of Technology, The Netherlands
}

\begin{abstract}
Rapid changes in society and student demographics pose major challenges for universities, who are responding by innovating education visions, learning goals, curricula, and courses. These education innovations are often reported in the literature and at conferences on a single-project basis, resulting in a large number of differently structured publications that make it difficult to find interesting examples or learn from a wide variety of education innovation projects. To counteract this, the four technical universities in the Netherlands (in Eindhoven, Wageningen, Twente, and Delft) offer standardized information about their education innovation projects on the innovation map website (4TU.CEE, 2020) of their joint Centre For Engineering Education; 4TU.CEE. University staff around the world can use the innovation map to find interesting examples of education innovation. Our analysis of all projects contained within the innovation map show that, over the last four years, the innovation priority of the four universities has been on solving present-day challenges in their courses. The main approach has been improving education design and optimizing blended learning. This has been particularly useful for the universities that faced a large growth in the number of students. In the future however, the priority of the four universities must shift to their longer-term strategies, such as Future Engineering Skills, Interdisciplinary Education, Dealing with Diversity, and Education Excellence. That also means more focus is needed for changes both to the curriculum and beyond. Furthermore, evaluation and dissemination should be more explicitly included. The purpose of the innovation map is to offer input for further university education innovation projects and research.
\end{abstract}

\section{KEYWORDS}

Education innovation, education vision, learning goals, curricula, course, education design, standards: $2,3,4,5,6,7,8,11,12$ 


\section{INTRODUCTION}

Our world becomes full of Volatility, Uncertainty, Complexity, and Ambiguity (Kamp, 2016). This has consequences for the position and task of universities, the learning goals for students, and the way students learn. Kamp (2019) describes the effects at the university level: "Science and Technology universities have to become much more socially engaged and culturally open to remain relevant and take the lead. They shall no longer produce knowledge for the world alone, but have to become more active in the world." He also sees clear effects on learning goals: "Engineering students have to learn that people, policies, environmental aspects, politics, economics, or cultural values often override disciplinary expertise." In addition, student populations are becoming more diverse, which has consequences for the design of courses (van Puffelen, 2017). For some universities the growth in the number of students dictates the redesign of courses and curricula.

Universities are responding to these challenges by innovating their education visions, learning goals, curricula, and courses. These education innovations are often reported in the literature and at conferences on a single-project basis, resulting in a large number of differently structured publications that make it difficult to find interesting examples or learn from a wide variety of education innovating projects. To counteract this, the four technical universities in the Netherlands (in Eindhoven, Wageningen, Twente and Delft) offer standardized information about their education innovation projects on the website (4TU.CEE, 2020) of their joint Centre For Engineering Education; 4TU.CEE. The website interface for this information is called the "innovation map", which enables users to select projects that are interesting to them and obtain standardized information to compare and learn from several projects. There are filters to select projects by theme or by many innovation characteristics, in addition to free-text search capabilities. Additional information, including the contact person, downloads, and links, help to explore each project further. The innovation map is an ongoing project itself; new projects are added constantly and the information can be updated by all staff members involved in the projects. It is the key information source on Education Innovation for the federation of the four Dutch universities of technology: 4TU (4TU, 2020). In addition the information on all projects can be used by university staff worldwide.

The projects reflect the combined effects of bottom-up and top-down innovation initiatives at the four Dutch technical universities over the last four years. Analyses of the project information enable those universities to better align their education innovation with their education strategies, generating results that might also be useful for universities worldwide. Tassone et al. (2020) developed a framework to analyze education innovation projects, consisting of 13 criteria. In the present study, three of those criteria are used to analyze the projects: reasons for innovation, evaluation of the projects, and dissemination. This analysis is supplemented by the distribution of the projects over the characteristics covered by the innovation map. 


\section{MATERIALS AND METHODS}

The information on the education innovation projects in the innovation map website is continually updated and extended by the staff involved in all projects and the 4TU.CEE. For the present study, the information available on January $20^{\text {th }}, 2020$ was used.

At that time there were 215 education innovation projects on the website, involving a total of 285 staff members (115 from Eindhoven, 95 from Wageningen, 49 from Twente, and 26 from Delft, including staff counted twice in joint projects). For each project, the relevance of one or more of six themes is indicated on the innovation map:

Active Learning \& Large Groups

Blended Learning \& Virtual Labs

Education Excellence \& Coaching

Future Engineering Skills

Interdisciplinary Education

Dealing with Diversity

First, the presence of each innovation theme was determined on the innovation map, for each course and curriculum innovation. This was supplemented with counts of any additional results (articles, workshops, and tools) and evidence-based innovations. In addition, all project texts were scanned to identify any detailed reasons for innovation, evaluation, and dissemination, the subset of the criteria developed by Tassone et al. (2020) explored in this study.

\section{RESULTS AND DISCUSSION}

The majority (192) of the 215 projects studied were course innovations (Table 1). Articles and workshops were relatively rare additional results, and about $25 \%$ of the projects also yielded a tool for teaching. Only 28 course innovation projects were reported to be evidencebased, indicating that personal judgement is typically used to steer the innovation. The results for the separate themes showed the same pattern.

Table 1. Distribution of results and themes for course innovations

\begin{tabular}{|c|c|c|c|c|c|}
\hline & \multirow{2}{*}{$\begin{array}{c}\text { Course } \\
\text { innovations }\end{array}$} & \multicolumn{3}{|c|}{ Additional results } & \multirow{2}{*}{$\begin{array}{c}\text { Evidence } \\
\text {-based }\end{array}$} \\
\hline & & Article & Workshop & Tool & \\
\hline Project total & 192 & 28 & 12 & 48 & 28 \\
\hline \multicolumn{6}{|l|}{ Themes (projects can have multiple) } \\
\hline Active learning \& large groups & 105 & 16 & 10 & 22 & 16 \\
\hline Blended Learning \& Virtual Labs & 88 & 10 & 6 & 26 & 9 \\
\hline Education Excellence \& Coaching & 74 & 7 & 1 & 26 & 11 \\
\hline Future Engineering Skills & 44 & 9 & 2 & 13 & 10 \\
\hline Interdisciplinary Education & 39 & 9 & 3 & 1 & 11 \\
\hline Dealing with Diversity & 36 & 6 & 4 & 8 & 6 \\
\hline
\end{tabular}

The lower part of Table 1 shows the distribution of themes in the course innovation projects, sorted by frequency. As each project can be geared towards multiple themes, the column 
totals for themes are higher than the total number of projects. The most frequently observed themes were Active Learning \& Large Groups, Blended Learning \& Virtual Labs, and Education Excellence \& Coaching. In general, these themes are important for present-day course challenges, but they might be geared to some longer-term goals as well. Less common themes were Future Engineering Skills, Interdisciplinary Education, and Dealing with Diversity. These themes include more adaptation towards the needs of the engineer of the future. It seems that, in past years, short-term challenges had a higher priority.

Only 68 of the 215 projects were curriculum innovations (Table 2), of which 45 also contained innovations at the course level. The reported education innovations were therefore mainly performed at the course level. Again, articles and workshops are relatively rare additional results for curriculum innovations, and about $25 \%$ of the projects also yielded a tool to be used in teaching. Only 13 curriculum projects were reported to be evidence-based. The results for the separate themes show the same pattern.

Table 2. Distribution of results and themes for curriculum innovations

\begin{tabular}{|l|c|c|c|c|c|}
\hline & Curriculum & \multicolumn{3}{|c|}{ Additional results } & Evidence \\
\cline { 3 - 6 } & innovation & Article & Workshop & Tool & \\
\hline -based
\end{tabular}

The lower section of table 2 shows the distribution of themes in the curriculum innovation projects, sorted by frequency. Again, the three most common themes are more geared towards present-day challenges, while the three less frequently observed themes include more innovation towards the needs of the engineer of the future. 
Projects can be defined within the six fixed themes in the innovation map. Project staff can also formulate their reasons for innovation freely within the project information text. The formulations found for all projects were grouped into six overarching reasons, as shown in Table 3.

Table 3. Reasons for innovation as reported in the project texts.

\begin{tabular}{|l|c|}
\hline Reasons for innovation & \\
\hline $\begin{array}{l}\text { Optimize education design and assessment (due to increasing } \\
\text { students/different needs), as well as coaching }\end{array}$ & 159 \\
\hline $\begin{array}{l}\text { Improve online learning for flexibility of learning and tackling } \\
\text { problems related to increasing student numbers and online safety }\end{array}$ & 63 \\
\hline Improve student motivation and interaction & 56 \\
\hline Dealing with diversity; knowledge level/cultures/work in groups & 41 \\
\hline Improve teacher education methods & 38 \\
\hline Future skills (planning, career choices, etc.) & 17 \\
\hline
\end{tabular}

The results for the freely formulated reasons for innovation reflect the same trend as seen in the themes in Tables 1 and 2 above; present-day challenges have been considered more important than long-term innovations geared towards the engineer of the future. The main topics are within the fields of the optimization of education design and blended learning.

Only 86 of the 215 projects reported an evaluation, with 14 of these 86 projects reporting two or three methods of evaluation. The most frequent approach was "implementation in courses/BSc program; evaluation afterwards by the project team", as shown in Table 4. That approach might include the standard course evaluation performed by the universities. This suggests that, in general, little additional effort was made to evaluate the 215 education innovation projects.

Table 4. Evaluation of the innovation projects as reported in the project texts.

\begin{tabular}{|l|r|}
\hline Will this innovation project be evaluated and how? & \\
\hline $\begin{array}{l}\text { Implementation in courses/BSc program; } \\
\text { evaluation afterwards by the project team }\end{array}$ & 54 \\
\hline Student course evaluation & 29 \\
\hline Evaluation of a pilot group & 11 \\
\hline Teacher evaluation & 5 \\
\hline Discussion with professor(s) & 4 \\
\hline
\end{tabular}


Most projects reported some dissemination activity; only 18 projects did not. The most frequent form of dissemination was an integration in the course(s)/BSc program involved, which was almost always the goal of the project anyway, as shown in Table 5. For 79 projects, there was a clear additional effort for the publication of an article. Other dissemination options were found to be less frequent.

Table 5. Dissemination of the innovation projects as reported in the project texts.

\begin{tabular}{|l|r|}
\hline In what way will this innovation project be disseminated? & \\
\hline Integrating in course(s)/BSc program & 86 \\
\hline Report/journal published & 79 \\
\hline Video & 26 \\
\hline Presentation & 22 \\
\hline Poster & 21 \\
\hline Handout/module & 18 \\
\hline Website & 5 \\
\hline Workshop & 3 \\
\hline
\end{tabular}

The results are similar to those reported by Tassone et al. (2020), who analyzed the characteristics of 88 course innovation project proposals at Wageningen University. Most of these projects are also included in the innovation map. For this subset, they found;

"Most intended innovations are driven by changes in student populations. To a lesser degree, they are driven by challenges in teaching, learning, and assessment, and by challenges with logistics and resources. Hardly any innovation is driven by changes in society. The most prominent reasons for innovation are the increasing number of students, and the related need for guaranteeing student learning and performance."

"More than half of the intended innovations do not include an evaluation strategy. Only 15\% of the proposals include and specify an evaluation strategy."

"Most innovations intend to disseminate results by providing detailed knowledge about the innovation, for example through a presentation of the innovation. Few proposals only intend to foster the further uptake of the innovations (dissemination for action)."

These findings are in line with the results of this study of the 215 projects at the four universities of technology; education innovation has focused more on present-day problems and less on long-term strategic goals. Tassone et al. (2020) reported even lower rates of evaluation and dissemination than are presented here, which could be because these researchers scanned the proposal texts, while the innovation map reports results including the less explicit evaluation and dissemination within the courses involved. 


\section{CONCLUSIONS}

The reported education projects run by the four Dutch technical universities show a focus on course-level innovations and present-day challenges. Furthermore, these projects indicate a preference for innovation by optimizing education design and balancing blended learning. These changes may have been introduced in response to the strong growth in student numbers experienced at these institutions over the past few years, particularly in the two universities with most reported projects, Wageningen and Eindhoven. Of course, strong student number growth is a very urgent challenge that must be tackled. The steps for optimizing education design were described by van Puffelen (2017), while advice for balanced blended learning was previously provided by van Puffelen, van Berkum, and Diederen (2018). Additionally, approaches for teaching large groups were proposed by Tho and den Brok (2019).

Present-day education challenges should not be the only focus of such innovation projects however, because the four Dutch universities of technology have longer-term strategic goals. These goals have been expressed in four topics within the 4TU.CEE strategic plan (den Brok et al., 2019):

1. Educating Future Engineers

2. Interdisciplinary Engineering Education

3. Engineering Educational Ecosystems

4. Teaching Excellence in University Engineering Education

To innovate towards these goals, the focus of innovation projects will have to shift to meet them. This will also require an innovation shift from the course level to the curriculum level and beyond. It would help to monitor this, if the tradition to mainly report course innovations is changed to more include the curriculum and above curriculum level. The addition of the beyond-curriculum level to the innovation map at the end of 2019 should facilitate the monitoring of its inclusion in innovation projects.

The evaluation and dissemination of the projects has mainly occurred within the innovated courses themselves; however, it would be better to explicitly include evaluation and dissemination actions in the proposals, project activity, and reports going forward.

The innovation map serves its purpose at its present scale of four universities. For staff around the world, it offers a flexible way to learn from the results of university education innovation projects. The Netherlands Initiative for Education Research (NRO) is interested in using this approach on a national scale, and its use on an international level such as offered by the CDIO initiative (CDIO, 2020) is another option. 


\section{ACKNOWLEDGMENTS}

We would like to thank Nicolette Tauecchio and Jun Hao Wu for their work in converting innovation map data into tables.

\section{REFERENCES}

4TU. (2020). 4TU.Federation; about 4TU. Retrieved from https://www.4tu.nl/en/about 4tu/

4TU.CEE. (2020). Innovation map of the 4TU Centre for Engineering Education.

Retrieved from https://www.4tu.nl/cee/en/innovation/

CDIO. (2020). Conceive Design Implement Operate. Retrieved from http://www.cdio.org/

den Brok, P., van Puffelen, E. A. M., van der Veen, J. T., Kamp, A., Pepin, B. E. U., et al. (2019). 4TU.Centre for Engineering Education, Strategic plan 2019-2021.

Retrieved from https://www.4tu.nl/cee/en/publications/4tu.cee-strategicplan-2019-2021-def.pdf

Kamp, A. (2016). Engineering Education in a Rapidly Changing World; Rethinking the Vision for Higher Engineering Education (Second Revised Edition ed.). Delft: Delft University of Technology, Faculty of Aerospace Engineering.

Kamp, A. (2019). Science and Technology Education for 21st Century Europe; CESAER discussion paper 18th december 2019. Retrieved from https://doi.org/10.5281/zenodo.3582544

Tassone, V., den Brok, P., Biemans, H., \& Runhaar, P. (2020). Characteristics of Intended, Implemented and Attained Educational Innovations at Wageningen University - A Research Study Executive Summary.

Retrieved from https://www.4tu.nl/cee/en/innovation/project/10577/characteristics-of-educationalinnovations-at-wageningen-university

Tho, C., \& den Brok, P. (2019). Teaching Large Groups. Retrieved from 4TU. Centre for Engineering Education: https://www.4tu.nl/cee/en/publications/2019-12-teaching-large-groups-final.pdf

van Puffelen, E. A. M. (2017). Designing blended engineering courses. Proceedings of the 45th SEFI Annual Conference 2017, Angra do Heroísmo - Terceira, Azores, Portugal. 1308-1312.

http://edepot.wur.nl/424719

van Puffelen, E. A. M., van Berkum, M., \& Diederen, J. (2018). Balancing online and face-to-face teaching and learning activities. Proceedings of the 14th International CDIO Conference, Kanazawa, Japan. 339-348. http://edepot.wur.nl/458051 


\section{BIOGRAPHICAL INFORMATION}

Emiel van Puffelen is the leader of the 4TU.Centre for Engineering Education at Wageningen University \& Research. At Wageningen University, he supervised the creation and full-scale operation of the University Teaching Qualification program. He also developed MOOC production teams, knowledge clip studios, the education innovation consultancy, the educational portal, and a team for the innovation of the IT learning environment. $\mathrm{He}$ is a senior consultant for the innovation of higher education and has worked for national organizations. He has a special interest in activating learning, blended learning, training teaching staff, and the novel design of curricula and courses.

Caroline Vonk is the 4TU.Centre for Engineering Education coordinator for Eindhoven University of Technology. She has a corporate background and is involved in coordinating and monitoring the research, development, and implementation of education innovation at the university. Furthermore, she collaborates in engineering education with the other three Dutch universities of technology within the 4TU.Centre for Engineering Education.

\section{Corresponding author}

Ir. Emiel A.M. van Puffelen

4TU.Centre For Engineering Education

Wageningen University \& Research

P.O. Box 9101

6700 HB Wageningen The Netherlands

31-317-484568

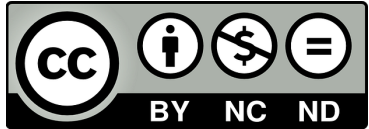

This work is licensed under a Creative Commons Attribution-NonCommercialNoDerivs 4.0 International License.

emiel.vanpuffelen@wur.nl 